Vol. 12 (1): 59-66 (2022)

\title{
THE CONDITIONS OF MARKET FISH POPULATIONS, THAT IMPACT ON SHKODRA LAKE STABILITY, WATER QUALITY AND SUSTAINABLE FISHING
}

\author{
Lulzime Dhora ${ }^{*}$ \\ I*University of Shkodra "Luigj Gurakuqi”, Faculty of Natural Sciences, \\ Water Research Centre of Shkodra Region, Albania; \\ *Corresponding Author Lulzime Dhora, e-mail: lulzime.dhora@unishk.edu.al;
}

Received October 2021; Accepted November 2021; Published January 2022;

DOI: https://doi.org/10.31407/ijees12.107

\begin{abstract}
Fishes are the component that performs the transport of nutrients in the pelagic of the Lake Shkodra. They constitute one of the few links of the food chains, which in food regimes is dominated by herbivorous-detrital structures and which contribute to the ecological stability. Market fishes constitute the main biomass of the lake fish community, therefore the study of the situation of their populations is important in terms of problems and management, for a sustainable fishing. Situations of fish populations have been studied through the assessment of threatened species (CR, EN, VU), based on declining of catch (IUCN, Version 3.1 of Red List of Threatened Species, 2001 Categories \& Criteria). Alburnus scoranza and Chondrostoma nassus are defined in the CR category. Carassius gibelio (that compete Cyprinus carpio), Perca fluviatilis and Leucos basak predominate in catch and should continue so for a long time. In the Montenegrin part of the lake there is a large decrease in the catch of migratory species to the sea. Catching of fish should be planned in accordance with the lake productivity, licensed for catching in detail by species, as well as controlled in detail. Factors leading to negative developments, such as water regime disturbance, the presence of pollutants, damage of the shore vegetation, erosion and especially illegal fishing, should also be monitored.
\end{abstract}

Keywords: market fish populations, impact, Shkodra lake, stability, water quality, sustainable fishıng. 